\title{
A highly diverse microcosm in a hostile world: a review on the associates of red wood ants (Formica rufa group)
}

\author{
T. Parmentier $\cdot$ W. Dekoninck $\cdot$ T. Wenseleers
}

Received: 8 May 2014/Revised: 20 June 2014 / Accepted: 25 June 2014

(C) International Union for the Study of Social Insects (IUSSI) 2014

\begin{abstract}
The importance of Eurasian red wood ants (RWAs) (Formica rufa group) in forest and heath ecosystems has long been recognized. One key function of RWAs is the role of their nests in supporting an intriguing ecosystem of a highly diverse group of obligate myrmecophiles and facultative guests. In this review we list 125 obligate arthropod myrmecophiles that occur in RWA mounds or in the near vicinity of the mounds. More than $40 \%$ of them are Coleoptera, but also Hemiptera, Diptera, Hymenoptera, Acari and Araneae are well represented. RWAs are estimated to be the primary hosts for 49 species. 24 species were hitherto only recorded to be associated with RWAs, 12 with both RWAs and other mound-building Formica species and 9 were found to be associated with both moundbuilding and non-mound-building Formica species. The remaining associates are less specific and can be found with other ant genera or ant subfamilies. Other mound-building Formica ants (Coptoformica, F. uralensis and F. truncorum) support fewer species, most of which are known to also occur with RWAs. We discuss the biology of the different obligate myrmecophilous groups and give general notes on the facultative guests found in RWA mounds. We stress the importance of the conservation of RWAs as hosts of one of the richest and diverse associations known to date in insects.
\end{abstract}

Electronic supplementary material The online version of this article (doi:10.1007/s00040-014-0357-3) contains supplementary material, which is available to authorized users.

T. Parmentier $\cdot$ T. Wenseleers

Laboratory of Socioecology and Socioevolution, KU Leuven,

Naamsestraat 59, box 2466, B-3000 Leuven, Belgium

T. Parmentier $(\bowtie) \cdot$ W. Dekoninck

Entomology Department, Royal Belgian Institute of Natural

Sciences, Vautierstraat 29, B-1000 Brussels, Belgium

e-mail: Thomas.Parmentier@bio.kuleuven.be
Keywords Red wood ants · Formicidae .

Formica rufa group · Myrmecophiles · Ant guests · Symbionts

\section{Introduction}

Eurasian red wood ants (Formica rufa group belonging to the subgenus Formica s.str.) are represented by six narrowly related and morphologically similar species: $F$. rufa, $F$. polyctena, F. pratensis, F. aquilonia, F. lugubris and F. paralugubris (Goropashnaya et al., 2004; Seifert, 2007). The mounds of these well-studied species are impressive markers in temperate and boreal forests and heath land across Eurasia. Their key roles have been appreciated since long: they are top predators that have a potential to control outbreaks of pest insects, they create nutrient heterogeneity in forests by concentrating food and organic material in their mounds and structure biotic and abiotic components of forests outside their nests (Gosswald, 1989; Frouz, 2000; Frouz et al., 2005; Domisch et al., 2008; Wardle et al., 2011). In addition, the presence of RWAs is vital for a large number of associated species living in the mounds or in their vicinity. The unique aspect of these species is that they have evolved mechanisms to overcome the aggression of their hosts and benefit from the resources and ideal nest conditions provided by their ant hosts. Since the nineteenth century, naturalists have begun to focus on the diversity and biology of RWA myrmecophiles. In the last decades, more and more elements of their hidden lifestyle have been revealed and the list of associated species has been growing longer and longer.

The striking diversity of RWA myrmecophiles can mainly be explained by the nest structure of RWAs. Their huge mounds provide stable and long-lasting habitats with 
controlled temperature and moisture (Rosengren et al., 1987). The mounds are also heterogenous in temperature, moisture and material (organic thatch material, inorganic soil, central stem) which create a large variety of microhabitats (Coenen-Stass et al., 1980; Rosengren et al., 1987). Furthermore, there is a constant supply of food and organic material which can sustain different trophic groups such as parasites, predators, scavengers, detritivores and mycophages (Skinner, 1980). Additionally, some species are attracted by the ant-tended aphid colonies that are typically present in the vicinity of the mounds.

Here, we did an exhaustive literature survey on RWA arthropod myrmecophiles. Literature search started from general reviews or studies on myrmecophiles. Then we scanned all groups for more specific published studies on RWA myrmecophiles. We aim to highlight the diversity of arthropods associated with Eurasian red wood ants and discuss their biology, distribution and host ant preference. We also give some notes on facultative associates which depend on RWAs and stress the need for RWA conservation and its associated myrmecophile community.

\section{RWA myrmecophiles: overview}

In our survey, we found reports of 125 arthropod myrmecophiles that have been found in association with red wood ants (Supplementary Table 1). Most of these live in the nests and are called inquilines. Additionally, some species live in the neighborhood of the nest or are parasites. Most species occur in nests of several ant hosts, whether or not belonging to different genera. Taxonomic information of the listed host ant species can be found in Supplementary Table 2. Most studies focused on myrmecophilous beetles. This sampling bias could contribute to their proportional high diversity. Other groups such as mites, flies and wasps are expected to have much more representatives, but studies on their diversity are hampered by less search effort, taxonomic problems (e.g., cryptic species) and poorly known distribution. The latter makes it hard to judge whether a species is strictly associated with ants or also occurs outside ant nests.

For many myrmecophiles, little is known about the biology or the actual type of interaction with the host ant, i.e., whether it is parasitic, commensalist or mutualistic. What is known about their biology, however, is reviewed below according to the taxonomic group to which they belong.

\section{Coleoptera}

More than $40 \%$ of RWA myrmecophiles belongs to this highly diverse group (Fig. 1). Rove beetles and particularly the subfamily Aleocharinae dominate the list of beetles. Traditionally, taxonomy, distribution and behavior of Coleoptera have been best studied (Wassmann, 1894; Janet, 1897; Donisthorpe, 1927; Hölldobler and Wilson, 1990). Myrmecophilous beetles range from highly integrated guests that are treated as nestmates (licking, feeding) to poorly integrated species that are heavily aggressed by the ants. Lomechusa (former Atemeles) and Lomechusoides (former Lomechusa) are textbook examples of highly integrated species. Lomechusa pubicollis adults emerge in an RWA nest in autumn and overwinter in a Myrmica nest. After hibernation they seek adoption again in an RWA nest to breed. Lomechusoides adults, in contrast, integrate in a nest of the same host ant species (Hölldobler and Wilson, 1990). Larvae and adults of Lomechusa and Lomechusoides have special glands that produce highly attractive substances. They live among the brood and are fed, licked and carried by the workers. They also feed on the brood of their host (Hölldobler, 1967, 1970). Hetaerius ferrugineus is a histerid beetle which is also highly integrated. It is a scavenger, but also solicits for liquid food and occasionally consumes ant brood. It is suggested that adoption is promoted by special trichome glands opening at the margin of the thorax. In case of an attack, it feigns death by oppressing its legs against its body (Hölldobler and Wilson, 1990). The rove beetle Dinarda is less integrated, but also steals regurgitated food from its ant host (Fig. 2a). When discovered, the beetle raises its abdomen and offers appeasement substances. If ant hostility continues, it can still rely on repellent secretions from the tergal gland (Hölldobler and Wilson, 1990). "Poorly" integrated rove beetles avert aggression by swift movements and/or by emitting repellent substances from their tergal gland (Hölldobler and Wilson, 1990). Some of them, such as Quedius brevis and Zyras humeralis, are mostly found in the winter when ant aggression is lowest (unpubl. data) (Fig. 2a). Many beetles are hardly noticed by the ants due to their small size and slow movement (e.g., Monotoma, Ptiliidae, Scydmaenidae, Pselaphinae) (Fig. 2a). Scydmaenidae, like Staphylinidae and Ptiliidae, are predisposed to a life in ant nests composed of decaying material (RWA, L. brunneus, L. fuliginosus) based on their preference for moist forest soils and rotten logs (Freude et al., 1974). O'Keefe (2000) mentions no less than 31 Scydmaenidae species associated with RWAs. Most of them, however, can regularly be found in the absence of ants in leaf litter and rotten logs and are rather facultative associates than obligate myrmecophiles (Freude et al., 1974; Tykarski, 2013). Here, we limit Supplementary Table 1 to Scydmaenidae that are classified as myrmecophiles according to Freude et al. (1974) and Tykarski (2013). Some associated beetles live (partly) outside the mound. Adults and larvae of the ladybird Coccinella magnifica are typically found on the 


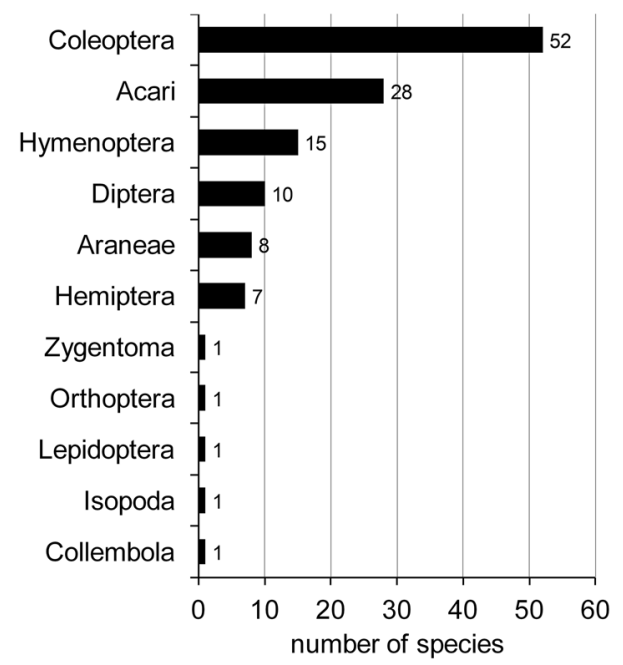

Fig. 1 Taxonomic distribution of myrmecophiles associated with RWAs

vegetation and on the trails near RWA mounds (Fig. 2c). Both feed on the aphid colonies tended by the ants. It was suggested that the adults can follow the trails of RWAs (Godeau, 1997). The behavior of the ladybirds is only slightly modified compared with its non-myrmecophilous congener $C$. septempunctata. They overcome ant aggression by running away and ducking down and possibly employ chemical adaptation (Sloggett et al., 1998). Clytra are remarkable leaf beetles with red elytra and black patches. Adults live on the trees and herbs near the nest and feed on plant leaves (Fig. 2d). The female drops the eggs near the nest and covers them with her excreta. The covered egg is very similar to plant material and is as a result sometimes carried by the ants and incorporated in the nest. The emerged larva permanently lives in the nest and builds a protective case made of its own excreta and earth. It mainly feeds on organic nest material and detritus (Fig. 2a). Fully grown larvae attach to the central stem or debris and pupate in their larval case (pers. obs. TP). Protaetia metallica (sometimes considered as a subspecies of Protaetia cuprea: Protaetia cuprea metallica, but see Renneson et al., 2012) has a similar alternating life cycle, with free-living adults and larvae confined to the mounds (Donisthorpe, 1927; Renneson et al., 2012) (Fig. 2b). The larvae, however, are not protected by a case, but resist attack through their tough skin and by boring deeper into the nest (Donisthorpe, 1927).

The highly integrated beetle species have special glandular adaptations to a myrmecophilous lifestyle. The adaptations of other beetles are less pronounced. They are morphologically very similar to nonmyrmecophilous relatives. The slender and small size of most beetles protects them from attacks. Still, the antennae of some

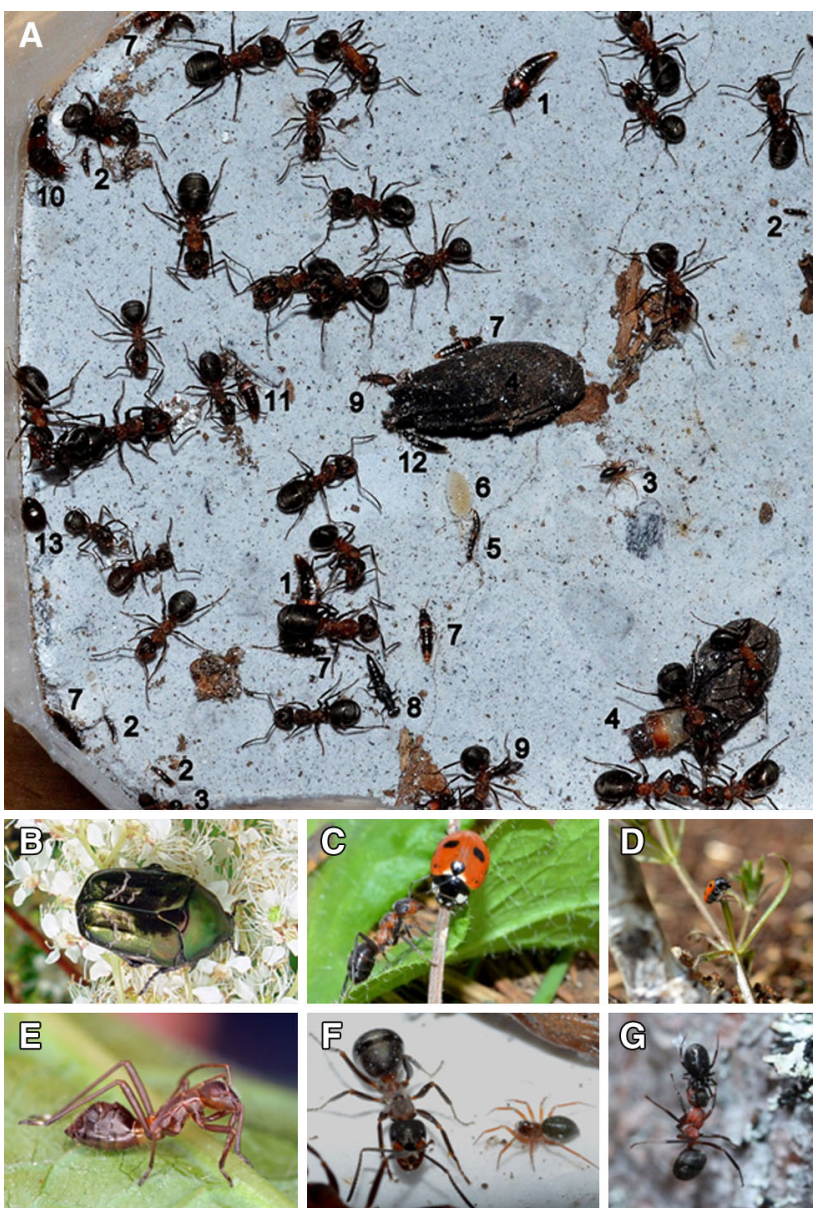

Fig. 2 Overview of RWA myrmecophiles. a A myrmecophile bestiary found in a Formica rufa nest in northern Belgium: (1) Dinarda maerkelii, (2) Amidobia talpa, (3) Thyreosthenius biovatus, (4) Clytra quadripunctata, (5) Leptacinus formicetorum, (6) Platyarthrus hoffmannseggii, (7) Thiasophila angulata, (8) Stenus aterrimus, (9) Monotoma, (10) Quedius brevis, (11) Notothecta flavipes, (12) Lyprorcorrhe anceps, (13) Myrmetes paykulli. b The imago of Protaetia metallica (photo courtesy of J.-L. Renneson). c A F. pratensis worker inspects a Coccinella magnifica searching for aphids above a nest mound. d Clytra quadripunctata imago above an F. rufa nest. e Nymphs of Alydus calcaratus are morphological mimics of Lasius and Formica ants (photo courtesy of Andreas Haselböck). f Thyreosthenius biovatus with an $F$. polyctena worker. g The myrmecophagous spider Dipoena torva feeds on an $F$. lugubris worker (photo courtesy of Gus Jones BSCG). Photo a, c, d, f by Thomas Parmentier

rove beetles associates (Thiasophila, Notothecta, Dinarda) are relatively compact to better withstand ant attacks (Freude et al., 1974) (Fig. 2a). Many myrmecophiles are known to mimic the cuticular chemical profile (chemical mimicry) of their ant host or have adaptations to remain undetected (chemical camouflage) (Dettner and Liepert, 1994; Akino, 2008; Bagnères and Lorenzi, 2010). These strategies have hitherto not been demonstrated in RWA myrmecophilous beetles or in other RWA myrmecophilous groups. 
Diptera

Syrphid flies of the genus Microdon are the best-studied myrmecophilous Diptera. Three species with a broad host range are known to be associated with RWAs. Adult flies look like typical flies, whereas the larvae have a unique slug-like appearance and locomotion. Young larvae are typically found deep in the nest and feed on detritus and ant brood. Larvae of M. mutabilis are ignored or if attacked by an ant worker seem unattractive. Nearctic Microdon larvae seem to be more integrated as they engage in chemical cuticular mimicry and are transported and licked by their hosts (Howard et al., 1990a, b). Older Microdon larvae migrate to the periphery of the nest where they pupate. The adults only live a few days and hover and mate in the near proximity of the nest where they emerged. Microdon populations are typically localized while potential hosts are widespread. Elmes et al. (1999) demonstrated that the survival of the eggs of M. mutabilis in Formica lemani declined dramatically when introduced in conspecific colonies situated only a few hundred meters away. The flies display extreme local adaptation not to one species, but to a local population of ants. Infiltration of M. mutabilis in the host ant nest does not involve chemical mimicry as demonstrated in Nearctic Microdon species (Hovestadt et al., 2012). It is probably mediated by a mimetic chemical coating on the egg scale (Elmes et al., 1999).

Information on the other Diptera is scarce. The adults of Phyllomyza formicae and Forcipomyia myrmecophila hover over the nests of mound-building Formicas and the larvae live in the nests, probably as scavengers. Holoplagia transversalis can be seen running on the trails and nest of its primary host Lasius fuliginosus, but it can also be collected with RWAs (Donisthorpe, 1927).

\section{Hemiptera}

In this order, we find inquilines that live in the RWA nests and species outside the nest and on trees in company with foraging ants. Species living outside the nest are mainly ant mimics gaining protection against their enemies by their resemblance to ants. They typically prey upon aphids or other insects, but also consume plant saps and honeydew (Wachmann et al., 2007). Pilophorus cinnamopterus and Pilophorus perplexus are rapid ant-like bugs with transverse silvery bands on the wings formed by pale hairs (Donisthorpe, 1927; Wachmann et al., 2007). Myrmecoris gracilis is a better mimic, with nymphs resembling dark Lasius workers and adults Formica workers (Wachmann et al., 2007). In constrast to Pilophorus, they have a petiolar constriction. The behavior and appearance of the early stages of Alydus calcaratus are also very ant-like. It occurs in heath land often in association with $F$. rufa, but also with other
Lasius and Formica species (Fig. 2e). Xylocoris formicetorum and Notochilus limbatus are two bugs occurring in the nests of mound-building Formicas. Both species are not antlike and little is known about their life history (Donisthorpe, 1927; Wachmann et al., 2007). They seem weakly integrated in the nests and probably hunt for mites and other mound associates (Wachmann et al., 2007). Eremocoris abietis, which is also not ant-like, can be found outside the nest and in the mounds where it most likely lives as a scavenger (Wachmann et al., 2007). Wasmann (1894) and Donisthorpe (1927) also report an association of Himacerus mirmicoides, Megacoelum beckeri, Philomyrmex insignis and Myrmedobia exilis with RWAs, but it is unlikely that this represents an obligate association (Wachmann et al., 2007).

\section{Hymenoptera}

The best-known representative of this order is the inquiline ant Formicoxenus nitidulus which lives in the nests of mound-building Formicas. Interestingly, the males are wingless and mating occurs on the mound surface. Formicoxenus is a genus of small social parasites with a xenobiotic lifestyle, i.e., they nest in the mound of RWAs, move freely among the hosts and obtain food from them, but their brood is kept separated (Hölldobler and Wilson, 1990). $F$. nitidulus are less associated with their hosts than the highly specialized congeneric species $F$. quebecensis and $F$. provancheri which are associated with a single Myrmica host and constantly lick their host to acquire cuticular hydrocarbons. In contrast, $F$. nitidulus have 11 hosts (Martin et al., 2007) and do not interact with their host. They are largely ignored and when seized dropped immediately because of an unattractive cuticular odor. They use a generalist chemical deterrent strategy which can be applied to several hosts, as opposed to chemical mimicry directed to one host species (Martin et al., 2007). Solenopsis fugax is another ant which can be found in RWA mounds, but also in nests of many other species. This tiny ant gets access to food and brood of their host by small galleries which are too narrow for their host (Janet, 1897; Donisthorpe, 1927).

Several wasps belonging to different families have been found hovering above RWA mounds. Trichopria fuliginosa and Conostigmus formiceti even live in ant mounds seemingly unharassed. For most species, little is known about their biology. They probably parasitize on the ant workers in or outside the nest, ant brood or other arthropods found in the nests. The oviposition behavior of some ant parasitoids has been recently recorded in detail (Gómez Durán and van Achterberg, 2011). Elasmosoma, Kollasmosoma and Neoneurus hover patiently over ant nests, then swiftly strike at an ant worker and finally oviposit with a hook-shaped ovipositor in the ant's gaster. They parasitize mostly Formica and it has been hypothesized that formic acid exuded by 
those ants could be a powerful attractant (Gómez Durán and van Achterberg, 2011). Hybrizon buccatus was observed while hovering over a Lasius grandis trail. Here, no oviposition was found on adult ants. Surprisingly, the wasp grasped a larva being transported on the trail and inserted an egg. The grasping of the ant or larva by the legs and the insertion of the ovipositor are species specific for the ant parasitoids.

\section{Lepidoptera}

From this order, only the moth Myrmecozela ochraceella lives in strict association with red wood ants (Wasmann, 1894; Donisthorpe, 1927). The larvae crawl through the nest and feed on the nest material. Similar to the case-building Clytra larvae, they spin tubes of silk and nest material in which they live and pupate. The yellowish adults reside in the vicinity of the mounds, but can also be found on and in the nest mounds (Donisthorpe, 1927). The well-studied Maculinea butterflies are confined to Myrmica nests and do not associate with RWAs.

\section{Acari}

Mites are the most diverse group found in red wood ant mounds, both in terms of abundance and number of species (Kielczewski and Wisniewski, 1962). The presented list of mites associated with RWAs probably reveals only the tip of the iceberg. Hypoaspis oophila is the most conspicuous mite as it exclusively lives in a large number on ant eggs. It appears that this mite does not puncture the eggs, but rather feeds on secretions coating the eggs (Donisthorpe, 1927). Most species are likely scavengers and some are known to be phoretic (Donisthorpe, 1927).

\section{Araneae}

The associated spiders can be divided into three groups: species that permanently live inside the mounds (= inquilines), myrmecomorphic species and myrmecophages. Thyreosthenius biovatus is a representative of the first group and only occurs in RWA mounds, but is probably abundant and widespread in RWA populations (Fig. 2a, f). This spider was found in $80 \%$ of RWA mounds in northern Flanders, Belgium (unpubl. data). The spider hardly elicits aggression and can walk freely among its ant host. Nymphs and females can be found throughout the year. Males are less abundant than females and probably occur only in spring and summer (pers. obs. TP). The heads of the males are raised in a conspicuous large lobe. Mastigusa arietina has a larger host range but is regularly associated with RWAs (unpubl. data). The white egg packets attached to wood pieces in the nest reveal their presence. Those spiders are mostly killed when placed together with RWAs in a cup, suggesting that this species is less integrated than T. biovatus (pers. obs. TP). The male palps are remarkably long and whip-like. Sometimes another morphologically similar species, Mastigusa macrophthalma is distinguished, but this is likely a subspecies (Heimer and Nentwig, 1991).The primary host of the inquiline spider Acartauchenius scurrilis is the small ant Tetramorium caespitum, but association with RWAs is also recorded (Donisthorpe, 1927). The second group comprises spiders that imitate their ant host morphologically and behaviorally, the so-called myrmecomorphic spiders. Three ant-mimicking spiders have been found in the vicinity of RWAs: Myrmarachne formicaria, Phrurolithus festivus and Micaria fulgens (Donisthorpe, 1927). Myrmarachne formicaria waves its forelegs to imitate antennation and walks very ant-like (Shamble et al., 2013). The chelicerae of the male of this spider are very pronounced. There is little information on the biology of those species, but most myrmecomorphic spiders are considered Batesian mimics (Cushing, 1997). Many animals do not prey on ants due to their toxicity, distastefulness and aggressive nature. By mimicking ants, myrmecomorphic spiders deceive potential predators and are avoided (Cushing, 1997). Recently, Davidson reported on the myrmecophagous behavior of Dipoena torva. This spider feeds exclusively on red wood ants ( $F$. aquilonia) in Scotland. It lives high on the tree stems and spins silk threads between the bark. RWA foragers get tangled with their antennae in the threads and are pierced by the spider in the soft membrane at the base of the antennae. The spider then manipulates the subdued ant away from the bark surface. Finally, the ant corpse hangs freely and is only attached to the stem with a small silk thread. This allows the spider to devour the ant without being attacked by other foragers (Fig. 2g). Simon (1997) reported the occurrence of this spider with RWAs ( $F$. polyctena) in Germany, but its dietary preferences and the behavior of this spider remain unknown. Dipoena tristis has a similar hunting strategy and has been found mostly on grass halms near the nest of Formica species (Wasmann, 1899).

\section{Panmyrmecophilous species}

Some obligate myrmecophiles do not show host preference and are associated with almost all ants in their habitat. Cyphoderus albinus, Atelura formicaria, Platyarthrus hoffmannseggii and Myrmecophilus acervorum are four typical panmyrmecophilous species that also co-occur with RWAs. They are the only representatives of the orders Collembola, Zygentoma, Isopoda and Orthoptera. They are all well adapted to a life underground: they lack or have greatly reduced eyes, $C$. albinus and $P$. hoffmannseggii are white in color and $M$. acervorum has lost wings (Donisthorpe, 1927; Junker, 1997). C. albinus is very characteristic 
by its erratic movements and $P$. hoffmannseggii by its thick, vibrating antennae (Fig. 2a). A major part of $M$. acervorum's diet consists of fluids regurgitated (trophallaxis) by the ant host (Junker, 1997). Both C. albinus and P. hoffmannseggii can reach high population densities in RWA mounds (unpubl. data).

\section{Facultative guests}

A vast array of species that are well known from outside ant nests were recorded in RWA mounds (Kielczewski and Wisniewski, 1962; Hlavac and Lackner, 1998; Laakso and Setälä, 1998; Stoev and Lapeva-Gjonova, 2005; LapevaGjonova and Lieff, 2012; Robinson and Robinson, 2013; Boer, 2014; Härkönen and Sorvari, 2014). Those species normally complete their life cycle without ants, but can facultatively be associated with RWAs. Some of the recorded species simply landed coincidentally in the mounds. However, many species across diverse taxa thrive in large numbers in the nests. Those species are attracted by the enrichment of organic material, ideal climatic conditions and constant supply of nutrients in the mounds. A study in Finland showed that the biomass of earthworms was about seven times higher in RWA mounds than in the surrounding soil. Their biomass exceeded the biomass of all other associates (Laakso and Setälä, 1997). Earthworms are much rarer in RWA mounds in northern Belgium. Instead, they are dominated by the common woodlouse Porcellio scaber (pers. obs. TP, WD). Some species, such as Xantholinus linearis and Drusilla caniculata, are designated as myrmecophiles because they often co-occur with ants. They can, however, also live away from ants and are therefore not myrmecophiles in the strict sense. The facultative myrmecophile fauna of RWAs consists mainly of animals associated with decaying vegetable material and bark. This includes Collembola, Acari, Pseudoscorpionida, Chilopoda, Diplopoda, Isopoda, Nematoda, Ptiliidae, Scydmaenidae, Staphylinidae and Psocoptera (Robinson and Robinson, 2013; Boer, 2014; pers. obs. TP, WD). Those species are mostly ignored by their size (Collembola, Acari, Psocoptera) or can avert ant aggression by swift movements (Staphylinidae, Chilopoda). Other ants, such as Leptothorax acervorum, have also been recorded in wood ant mounds (Donisthorpe, 1927). Isopods and diplopods have a strong exoskeleton, but are rarely attacked. The concentration of cuticular hydrocarbons, which ants use as kin recognition keys, is probably low in those species as suggested in Kärcher and Ratnieks (2010). When there are few records of a species, it can be troublesome to determine its status as an obligate or facultative associate. For example, Henderickx (2011) described a new myrmecophilous pseudoscorpion species Allochernes struyvei based on individuals found in one $F$. paralugubris mound. More records, however, are needed to confirm its status of true myrmecophile.

\section{Distribution}

Eurasian RWAs have a very broad distribution covering boreal and temperate Europe and large parts of Russia (Goropashnaya et al., 2004). The distribution of many associated RWA myrmecophiles is concordant with their host ant species. For example, the beetles Thiasophila angulata, Amidobia talpa and Monotoma conicollis are recorded with RWAs in Great Britain, Scandinavia, continental Europe and Siberia. In contrast, some of the listed species have a narrower distribution. Clytra laeviscula for example is restricted in Europe to the southern and central part, while the related Clytra quadripunctata can be found throughout Europe with RWAs. Atelura formicaria and Myrmecophilus acervorum are also thermophilous species that do not live in northern Europe. The hidden life of the associates makes it hard to estimate their abundance. Some species are fairly common in RWA populations and can attain high local densities (Päivinen et al., 2004; unpubl. data), but wasps, flies and true bugs are much rarer and some of them are hardly recorded. This difference however can be partly attributed to a focus on the study of myrmecophilous beetles while other groups are often neglected.

\section{Host preference}

RWAs are believed to be the primary host of about $40 \%$ of the species in our survey (Supplementary Table 1: indicated with *). Moreover, 24 species have hitherto only been recorded with RWAs (Fig. 3) (Note that some poorly known species, especially mites, could have a broader host distribution than hitherto recorded). Additionally, there are indications that some RWA myrmecophiles prefer a particular RWA species, e.g., Oxypoda pratensicola and Thiasophila lohsei typically live in association with $F$. pratensis. Some species are restricted to mound-building Formicas, which includes RWAs, F. truncorum (Formica s. str.), Coptoformica and F. uralensis (Supplementary Table 3). Mound-building Formica species that do not belong to the $F$. rufa group have a less diverse myrmecophile association: 46 associates (species listed in Supplementary Table $1+$ two panmyrmecophilous species + species in Supplementary Table 3) have been found with Coptoformi$c a, F$. truncorum and $F$. uralensis so far, from which only five species have not been recorded with RWAs (Supplementary Table 3). Conversely, there are 84 RWA myrmecophiles not found with other mound-building Formicas. Some species such as Dinarda hagensii and 


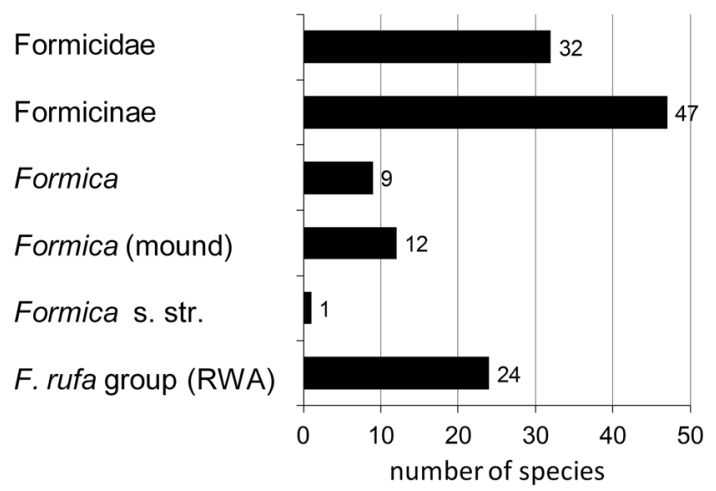

Fig. 3 Taxonomic distribution of all recorded hosts of myrmecophiles associated with RWAs (based on column 4 in Supplementary Table 1)

Thiasophila canaliculata have $F$. exsecta (Coptoformica) as primary host. The lower diversity of myrmecophiles associated with non-RWA mound-building Formicas can be explained by a smaller geographic range, smaller nests and possibly also by a sampling bias. A few species can be found with several species of the genus Formica, including both mound-building Formica ants as well as Raptiformica (F. sanguinea sometimes builds small mounds, but is here not considered as mound building because its nests can regularly be found under stones, in the ground or in tree trumps) and Serviformica ants. RWA queens found new colonies by parasitizing Serviformica colonies (Hölldobler and Wilson, 1990). This takeover behavior could promote the association of myrmecophiles, both with Serviformica and mound-building Formicas. A large part of the species has also been found with Camponotus and/or Lasius: two other genera of the subfamily Formicinae. RWAs share many myrmecophiles especially with L. fuliginosus and L. brunneus, probably because they all construct nests with decaying organic material. About a quarter of the myrmecophiles have also been found with other subfamilies of the Formicidae. These include the panmyrmecophilous species and also other species with more restricted host range across non-related taxa (e.g., Lomechusa species that switch host in winter). Many myrmecophiles succeeded to integrate in the wood ant mounds, but few are host specific (24 species exclusively found in RWAs). It can be expected that most species associated with RWAs rather apply general strategies, such as swift movements, defense chemicals (Staphylinidae: tergal gland), small compact size, hard exoskeleton, chemical insignificance, death feigning, ducking and avoidance. These general strategies facilitate easy host switching.

\section{Conservation}

RWA populations are under increasing pressure by intensive agriculture, habitat fragmentation, deforestation, urbanization, habitat deterioration (e.g., overgrowing shrubs) and recreation (Sorvari and Hakkarainen, 2005, 2007; Dekoninck et al., 2010, Gyllenstrand and Seppä, 2003; Mäki-Petäys et al., 2005). The six species of the $F$. rufa group are listed on the IUCN Red List of Threatened species (IUCN 2013) and are protected in most European countries. Initially, the awareness of the role of RWAs in controlling pest insects stimulated conservationists (Gosswald, 1989). Later their importance for nutrient soil cycles and their complex social organization has encouraged conservation measures. However, the importance of their nests for myrmecophiles and other associated species has often been overlooked. Population sizes and prevalences of myrmecophiles decrease when RWA mounds become more isolated (Päivinen et al., 2004, Härkönen and Sorvari, 2014; unpubl. data). It can be expected that myrmecophiles strictly bound to RWAs are affected the most by the deterioration of population densities of their host. However, myrmecophiles that also occur with other ant hosts likely suffer from a decline in wood ant nests as well. For those species, the rich organic, thermoregulated and stable mounds are likely source habitats in which they can attain high population densities (unpubl. data). Dispersal from those patches to surrounding nests of other ant hosts, which are often of lower quality and short-lived, can be vital in the population dynamics of those species. RWAs can thus be considered as typical flagship species and their protection should be primordial to conserve a highly diverse group of associated species.

Acknowledgments This project was supported by the FWOVlaanderen (Research Foundation Flanders) (grant no.11D6414N) and by the KULeuven PF/10/07-SEEDS grant (Centre of excellence on eco-evolutionary dynamics).

\section{References}

Akino T. 2008. Chemical strategies to deal with ants: a review of mimicry, camouflage, propaganda and phytomimesis by ants (Hymenoptera: Formicidae) and other arthropods. Myrmecol. News 11: 173-181

Andersson H. 1974. Studies on the myrmecophilous fly, Glabellula arctica (Zett.) (Dipt. Bombyliidae). Insect Syst. Evol. 5: 29-38

Boer P. 2013. De Nederlandse mieren - species found in wood ant mounds in the Netherlands. <http://www.nlmieren.nl/ websitepages/woodant $\% 20$ mounds.html $>$, retrieved on 1 February 2014

Bagnères A.-G. and Lorenzi M.C. 2010. Chemical deception/mimicry using cuticular hydrocarbons. In: Insect Hydrocarbons: Biology, Biochemistry and Chemical Ecology (Blomquist G.J. and Bagnères A.-G., Eds), Cambridge: Cambridge University Press. pp 282-324

Brooks J.L. 1942. Notes on the ecology and the occurrence in America of the myrmecophilous sowbug, Platyarthus hoffmanseggi Brandt. Ecology 23: 427-437 
Chopard L. 1951. Faune de France Orthoptéroïdes. Paul Lechevalier, Paris

Coenen-Stass D., Schaarschmidt B. and Lamprecht I. 1980. Temperature distribution and calorimetric determination of heat production in the nest of the wood ant, Formica polyctena (Hymenoptera, Formicidae). Ecology 61: 238-244

Cushing P.E. 1997. Myrmecomorphy and myrmecophily in spiders: a review. Florida Entomol. 80: 165-193

Davidson M. 2011. Some observations on the wood ant spider (Dipoena torva). <www.woodants.org.uk $>$, retrieved on 5 February 2014

Dekoninck W., Lock K. and Janssens F. 2007. Acceptance of two native myrmecophilous species, Platyarthrus hoffmannseggii (Isopoda: Oniscidea) and Cyphoderus albinus (Collembola: Cyphoderidae) by the introduced invasive garden ant Lasius neglectus (Hymenoptera: Formicidae) in Belgium. Eur. J. Entomol. 104: 159-161

Dekoninck W., Hendrickx F., Grootaert P. and Maelfait J. 2010. Present conservation status of red wood ants in north-western Belgium: Worse than previously, but not a lost cause. Eur. J. Entomol. 107: 209-218

Dettner K. and Liepert C. 1994. Chemical mimicry and camouflage. Annu. Rev. Entomol. 39: 129-154

Domisch T., Ohashi M. and Finér L. 2008. Decomposition of organic matter and nutrient mineralisation in wood ant (Formica rufa group) mounds in boreal coniferous forests of different age. Biology and Fertility of soils 44: 539-545

Donisthorpe H.S.J.K. 1927. The Guests of British Ants, their Habits and Life-Histories. George Routledge and Sons, London

Ebermann E. 1980. Zur Kenntnis der Ostalpinen Milbenfauna (Acari, Fam. Scutacaridae). Mitt. Naturwiss. Ver. Steiermark 110: 143-149

Elmes G.W., Barr B., Thomas J.A. and Clarke R.T. 1999. Extreme host specifcity by Microdon mutabilis (Diptera: Syrphidae), a social parasite of ants. Proc. R. Soc. Lond. B 266: 447-453

Evans G.O. and Till W.M. 1966. Studies on the British Dermanyssidae (Acari: Mesostigmata). Part II. Classification. Bulletin of The British Museum (Natural History) Zoology 14: 107-370

Fain A. and Chmielewski W. 1987. The phoretic hypopi of two acarid mites described from ants' nest: Tyrophagus formicetorum Volgin, 1948 and Lasioacarus nidicolus Kadzhaja and Sevastianov, 1967. Acarologia 28: 53-61

Fowles A.P. 1994. A review of the ecology of the red wood ant Formica rufa L. (Hymenoptera, Formicidae) and its status in Wales. Cons. Ecol. Wales 1: 1-22

Freude H., Harde K.W. and Lohse G.A. 1974. Die Käfer Mitteleuropas. Band 5, Staphylinidae II (Hypocyphtinae und Aleocharinae). Pselaphidae. Krefeld: Goecke et Evers Verlag

Frouz J. 2000. The effect of nest moisture on daily temperature regime in the nests of Formica polyctena wood ants. Insect. Soc. 47: 229-235

Frouz J., Kalcik J. and Cudlín P. 2005. Accumulation of phosphorus in nests of red wood ants Formica s. str. Annal. Zool. Fenn. 42: 269-275

Godeau J.-F. 1997. Les stratégies écologiques de la coccinelle myrmécophile Coccinella magnifica Redtenbacher. Doctoral thesis, Faculté Universitaire des Sciences Agronomiques de Gembloux

Gómez Durán J.-M. and van Achterberg C. 2011. Oviposition behaviour of four ant parasitoids (Hymenoptera, Braconidae, Euphorinae, Neoneurini and Ichneumonidae, Hybrizontinae), with the description of three new European species. ZooKeys 106: $59-106$

Goropashnaya A. V, Fedorov V.B. and Pamilo P. 2004. Recent speciation in the Formica rufa group ants (Hymenoptera, Formicidae): inference from mitochondrial DNA phylogeny. Mol. Phylogen. Evol. 32: 198-206
Gosswald K. 1989. Die Waldameise. Band 2. Die Waldameise im Ökosystem Wald, ihr Nutzen und ihre Hege. Aula-Verlag Wiesbaden

Gyllenstrand N. and Seppä P. 2003. Conservation genetics of the wood ant, Formica lugubris, in a fragmented landscape. Mol. Ecol. 12: 2931-2940

Härkönen S. and Sorvari J. 2014. Species richness of associates of ants in the nests of a red wood ant Formica polyctena. Insect Cons. Diversity: 1-11

Heimer S. and Nentwig W. 1991. Spinnen Mitteleuropas. Verlag Paul Parey, Berlin und Hamburg

Henderickx H. 2011. A new myrmecophilous Allochernes from ant nests in the high altitude of the eastern Spanish Pyrenees (Arachnida: Pseudoscorpiones: Chernetidae). Bulletin S.R.B.E/ K.B.V.E. 147: 79-83

Hlavac P. and Lackner T. 1998. Contribution to the knowledge of myrmecophilous beetles of Slovakia. Entomofauna carpathica 10: $1-9$

Hlavac P. 2005. Revision of the myrmecophilous genus Lomechusa (Coleoptera: Staphylinidae: Aleocharinae). Sociobiology 46: 203-250

Hölldobler B. 1967. Zur Physiologie der Gast-Wirt-Beziehungen (Myrmecophilie) bei Ameisen I. Das Gastverhältnis der Atemeles- und Lomechusa-Larven (Col. Staphylinidae) zu Formica (Hym. Formicidae). Z. vergl. Physiol. 56: 1-21

Hölldobler B. 1970. Zur Physiologie der Gast-Wirt-Beziehungen (Myrmecophilie) bei Ameisen II.1 Das Gastverhältnis des imaginalen Atemeles pubicolis Bris. (Col. Staphylinidae) zu Myrmica und Formica (Hym. Formicidae). Z. vergl. Physiol. 66: 215-250

Hölldobler B. and Wilson E.O. 1990. The Ants. Harvard University Press Cambridge, Massachusetts

Hovestadt T., Thomas J.A., Mitesser O. and Elmes G.W. 2012. Unexpected benefit of a social parasite for a key fitness component of its ant host. Amer. Nat. 179: 110-123

Howard R.W., Akre R.D. and Garnett W.B. 1990a. Chemical mimicry in an obligate predator of carpenter ants (Hymenoptera: Formicidae). Annals Entomol. Soc. Am. 83: 607-661

Howard R.W., Stanley-Samuelson D.W. and Akre R.D. 1990b. Biosynthesis and chemical mimicry from the obligate predator Microdon albicomatus and its ant prey, Myrmica incompleta Provancher (Hymenoptera: Formicidae). J. Kansas Entomol. Soc. 63: $437-443$

Huhta V. and Karg W. 2010. New species in genera Hypoaspis (s. lat.) Canestrini, 1884, Dendrolaelaps (s. lat.) Halbert, 1915, and Ameroseius Berlese, 1903 (Acari, Gamasina) from Finland. Soil Organisms 82: 325-349

IUCN 2013. The IUCN red list of threatened species. <http://www. iucnredlist.org/>, retrieved on 15 February 2014

Janet C. 1897. Etudes sur les fourmis, les guêpes et les abeilles. Note 14: Rapports des animaux myrmécophiles avec les fourmis. Ducourtieux, Limoges

Junker E.A. 1997. Untersuchungen zur Levensweise und Entwicklung von Myrmecophilus acervorum (PANZER, 1799) (Saltatoria, Myrmecophilidae). Articulata 12: 93-106

Junker E.A. and Ratschker U.M. 2000. Zur Verbreitung der Ameisengrille, Myrmecophilus acervorum (Panzer, 1799), in Sachsen (Insecta; Ensifera; Myrmecophilidae). Faun. Abh. Staatlich. Mus. Tierkunde Dresden 22: 11-21

Karafiat H. 1959. Systematik und Ökologie der Scutacariden. In: Uppstrom K. A. 2010. Mites (Acari) associated with the ants (Formicidae) of Ohio and the harvester ant, Messor pergandei, of Arizona

Kärcher M.H. and Ratnieks F.L.W. 2010. Honey bee guards recognise allospecific intruders via "different odours" not "harmfulintruder odours.” J. Apicult. Res. 49: 270-277 
Kielczewski B. and Wisniewski J. 1962. Z badań nad akarofauną gniazd Formica rufa L. i Formica polyctena Forst. na tle pozostałych stawonogów towarzyszących (From studies on the Acarofauna of Formica rufa L. Formica polyctena Först. nests on the background of other accompanying Arthropoda). Prace $z$ Zakresu Entomologii Lesnej 13: 3-14

Laakso J. and Setälä H. 1997. Nest mounds of red wood ants (Formica aquilonia): hot spots for litter-dwelling earthworms. Oecologia 111: 565-569

Lachaud J.-P. and Pérez-Lachaud G. 2012. Diversity of Species and Behavior of Hymenopteran Parasitoids of Ants: A Review. Psyche: A Journal of Entomology 2012: 1-24

Lapeva A. and Simov N. Xylocoris formicetorum (Bohemann, 1844) (Heteroptera: Anthocoridae), a new member of the myrmecophilous fauna of the Balkan Peninsula. Hist. Nat. Bulgarica 12, 29-31

Lapeva-Gjonova A. and Rücker W.H. 2011. Latridiidae and Endomychidae beetles (Coleoptera) from ant nests in Bulgaria. Latridiidae 8: 5-8

Lapeva-Gjonova A. and Lieff O. 2012. Ant-associated rove beetles (Coleoptera: Staphylinidae) in Bulgaria. Acta Entomol. Slovenica 20: $73-84$

Lapeva-Gjonova A. 2013. Ant-associated beetle fauna in Bulgaria: A Review and New Data. Psyche: J. Entomol. 2013: 1-14

Lehtinen P.T. 1987. Association of uropodid prodinychid polyaspidid antennophorid sejid microgynid and zerconid mites with ants. Entomol. Tidskr. 2: 13-20

Lommelen E., Johnson C.A., Drijfhout F.P., Billen J., Wenseleers T. and Gobin B. 2006. Cuticular hydrocarbons provide reliable cues of fertility in the ant Gnamptogenys striatula. Journal of Chemical Ecology 32: 2023-2034

Mäki-Petäys H., Zakharov A., Viljakainen L., Corander J. and Pamilo P. 2005. Genetic changes associated to declining populations of Formica ants in fragmented forest landscape. Mol. Ecol. 14: 733-42

Mahunka S. 1967. Beiträge zur kenntnis der Tschechoslowakischen Tarsonemini- fauna. Věstník Česk. Spol. Zool. 31: 240-244. In: Uppstrom, K. A. 2010. Mites (Acari) associated with the ants (Formicidae) of Ohio and the harvester ant, Messor pergandei, of Arizona. Master thesis Ohio State University

Mahunka S. 1970. Zwei neue Heterodispus- Arten und einige interessante in Ameisenhaufen lebende milben aus Ungarn (Acari: Tarsonemina). Folia Entomol. Hung. 23: 313-331. In: Uppstrom K. A. 2010. Mites (Acari) associated with the ants (Formicidae) of Ohio and the harvester ant, Messor pergandei, of Arizona. Master thesis Ohio State University

Martin S.J., Jenner E. and Drijfhout F.P. 2007. Chemical deterrent enables a socially parasitic ant to invade multiple hosts. Proc. R. Soc. B 274: 2717-2722.

O'Keefe S. 2000. Ant-like stone beetles, ants, and their associations (Coleoptera: Scydmaenidae; Hymenoptera: Formicidae; Isoptera). J. N.Y. Entomol. Soc. 108: 273-303

Päivinen J., Ahlroth P., Kaitala V., Kotiaho J.S., Suhonen J. and Virola T. 2003. Species richness and regional distribution of myrmecophilous beetles. Oecologia 134: 587-595

Päivinen J., Ahlroth P., Kaitala V., Kotiaho J.S. and Suhonen J. 2004. Species richness, abundance and distribution of myrmecophilous beetles in nests of Formica aquilonia ants. Ann. Zool. Fenn. 41: 447-454

Reemer M., Renema W., van Steenis W., Zeegers T., Barendregt A., Smit J.T., van Veen M.P., van Steenis J. and van der Leij L.J.J.M. 2009. De Nederlandse zweefvliegen (Diptera: Syrphidae). - Nederlandse Fauna 8. Leiden. Nationaal Natuurhistorisch Museum Naturalis, KNNV Uitgeverij, European Invertebrate Survey - Nederland

Renneson J.-L., Drumont A., Grotz R. and Dekoninck W. 2012. A propos de Protaetia (Potosia) metallica (Herbst, 1782) en Belgique et au Grand-Duché de Luxembourg (Coleoptera, Scarabaeidae, Cetoniinae). Lambillionea 3: 263-279
Rettenmeyer C.W., Rettenmeyer M.E., Joseph J. and Berghoff S.M. 2010. The largest animal association centered on one species: the army ant Eciton burchellii and its more than 300 associates. Insect. Soc.: 58: 281-292

Robinson N.A. and Robinson E.J.H. 2013. Myrmecophiles and other invertebrate nest associates of the red wood ant Formica rufa (Hymenoptera: Formicidae) in north-west England. Brit. J. Entomol. Nat. Hist. 26: 67-88

Rolstad J., Løken B. and Rolstad E. 2000. Habitat selection as a hierarchical spatial process: the green woodpecker at the northern edge of its distribution range. Oecologia 124: 116-129

Rosengren R., Fortelius W., Lindström K. and Luther A. 1987. Phenology and causation of nest heating and thermoregulation in red wood ants of the Formica-rufa group studied in coniferous forest habitats in southern Finland. Ann. Zool. Fenn. 24: 147-155

Shamble P.S., Beatus T., Cohen I. and Hoy R. 2013. Terrestrial locomotor mimicry at the kinematic level: Does the ant-mimicking jumping spider Myrmarachne formicaria walk like an ant? SICB Annual Meeting 2013 January 3-7, 2013 San Francisco, CA

Simon U. 1997. On the biology of Dipoena torva (Araneae: Theridiidae). Arachnol. Mitt. 13: 30-41

Seifert B. 2007. Die Ameisen Mittel- und Nordeuropas. lutra Verlagsund Vertriebsgesellschaft, Görlitz

Skinner G. 1980. The feeding habits of the wood-ant, Formica rufa (Hymenoptera: Formicidae), in limestone woodland in north-west England. J. Anim. Ecol. 49: 417-433

Sloggett J.J., Wood R.A. and Majerus M.E.N. 1998. Adaptations of Coccinella magnifica Redtenbacher,, a myrmecophilous coccinellid, to aggression by wood ants (Formica rufa group). I. Adult behavioral adaptation, its ecological context and evolution. Evolution 11: 889-904

Sorvari J. and Hakkarainen H. 2005. Deforestation reduces nest mound size and decreases the production of sexual offspring in the wood ant Formica aquilonia. Ann. Zool. Fenn. 42: 259-267

Sorvari J. and Hakkarainen H. 2007. Wood ants are wood ants: deforestation causes population declines in the polydomous wood ant Formica aquilonia. Ecol. Entomol. 32: 707-711

Staniec B. and Zagaja M. 2008. Rove-beetles (Coleoptera, Staphylinidae) of ant nests of the vicinities of Leżajsk. Ann. Univ. Mariae Curie-Sklodowska Lublin - Polonia 63: 111-127

Stoev P. and Lapeva-Gjonova A. 2005. Myriapods from ant nests in Bulgaria (Chilopoda, Diplopoda). Peckiana 4: 131-142

Storey M. BioInfo (UK) 2014. <www.bioinfo.org.uk>, retrieved on 5 March 2014

Storkan J. 1940. Myrmekofiln Acari z Cech. Vestnik Cesk. Zool. Spol. 8: $166-172$

Tykarski P. 2013. Coleoptera Poloniae - Information System about Beetles of Poland. $<$ http://coleoptera.ksib.pl/index.php?id=cretl= en $>$, retrieved on 10 February 2014

Uppstrom K. A. 2010. Mites (Acari) associated with the ants (Formicidae) of Ohio and the harvester ant, Messor pergandei, of Arizona. Master thesis Ohio State University

Wachmann E., Melber A. and Deckert J. 2007. Wanzen. Goecke et Evers, Keltern

Wardle D., Hyodo F. and Bardgett R. 2011. Long-term aboveground and belowground consequences of red wood ant exclusion in boreal forest. Ecology 92: 645-656

Wasmann E. 1894. Kritisches Verzeichniss der myrmekophilen und termitophilen Arthropoden. Berlin: F. L. Dames, xv

Wasmann E. 1898. Erster Nachtrag zu den Ameisengästen von Holländisch Limburg, mit biologischen Notizen. Tijdschr. Entomol. 41: 1-19

Wasmann E. 1899. Weitere nachträge zum Verzeichniss der Ameisengäste von Holländisch Limburg. Tijdschr. Entomol. 42: 158-171 